\title{
URGENSI MEMPELAJARI FIKIH MUAMALAH DALAM MERESPON EKONOMI DAN KEUANGAN KONTEMPORER (Membangun Paradigma Ekonomi Syariah di Masyarakat)
}

\author{
Muhammad Syarif Hidayatullah ${ }^{1}$
}

\section{Abstrak}

Manusia sebagai makhluk sosial dalam menjalani kehidupan di dunia tidak lepas dari aktivitas ekonomi. Interaksi ekonomi baik bersifat komersial maupun sosial terjadi setiap harinya. Produk dan jasa keuangan yang baru dan beragam hadir di tengah masyarakat sebagai sarana memenuhi kebutuhan dalam perekonomian modern. Syariat Islam yang komprehensif dan universal selain mengatur masalah ibadah juga mengatur masalah muamalah dengan problematika ekonomi yang berada dalam dimensi syariah. Dengan begitu, sangat penting untuk seorang muslim mempelajari fikih muamalah dalam merespons ekonomi dan keuangan kontemporer. Kedudukan fikih muamalah dalam khazanah keislaman begitu penting untuk dipelajari oleh umat Islam, karena keilmuan fikih muamalah adalah bekal utama untuk dapat memilah antara sah dan batil atau halal dan haram dalam ekonomi dan keuangan yang berdampak pada terwujudnya perekonomian syariah. Selain itu peran majelis taklim dengan pengajian fikih muamalah adalah vital sebagai media dakwah ekonomi syariah untuk membangun paradigma ekonomi syariah di masyarakat dengan alur berkelanjutan pada perjuangan memasyarakatkan ekonomi syariah di atas jalan jihad ekonomi.

Kata Kunci: Mempelajari Fikih Muamalah, Paradigma Ekonomi Syariah, Ekonomi dan Keuangan Kontemporer

\section{Abstract}

Human beings as social beings in living life in the world can not be separated from economic activities. Economic interactions both commercial and social occur every day. New and diverse financial products and services are present in the community as a means of meeting the needs in the modern economy. Comprehensive and universal Islamic law in addition to regulating the issue of ibadah (worship) also regulates the isuue of muamalah (social interaction) with economic problems that are in the shariah dimension. That way, it is very important for a Muslim to learn the figh muamalah (Islamic jurisprudence on economics) in responding to contemporary economics and finance. The position of figh muamalah in the islamic treasures is so important to be studied by Muslims, because science figh muamalah is the main provision to be able to sort between legitimate and vanity or halal

${ }^{1}$ Program Doktor Ilmu Syariah Pascasarjana UIN Antasari Banjarmasin, Email: syarif.muhammad849@gmail.com

URGENSI MEMPELAJARI FIKIH MUAMALAH DALAM 
and haram in the economy and finance that has an impact on the realization of the Islamic economy. In addition, the role of the Majlis Ta'lim with the study of fiqih muamalah is vital as a medium of Islamic economic da'wah to build a paradigm of Islamic economy in society with a sustainable flow in the struggle to socialize the Islamic economy on the path of economic jihad.

Keywords: Learn Figh Muamalah, Islamic Economic Paradigm, contemporary economics and finance

\section{A. PENDAHULUAN}

Problematika ekonomi dan bisnis termasuk persoalan yang diatur dalam syariat Islam. Islam mendeskripsikan, mengonseptualisasi, menstrukturisasi aturan hukum, dan menunjukkan varian usaha yang beraneka ragam, sehingga dapat menjadi pedoman bagi para pelaku ekonomi. Dengan memperhatikan rambu-rambu yang telah ditetapkan, mereka dapat menjauhi hal-hal yang diharamkan. Dengan barada di bawah syariat tersebut, mereka dapat bekerja, berniaga dan membangun perekonomian dalam rangka merealisasikan kepentingan dan kebutuhan hidup secara adil dengan tidak lepas dari aturan hukum yang bersumber dari al-Qur'an dan hadits serta memperhatikan tujuan disyariatkannya sebuah hukum (maqâshid asy-syarî'ah).

Ayat al-Qur'an yang berisi anjuran bekerja seperti QS. al-Isrâ ayat 12 berikut:

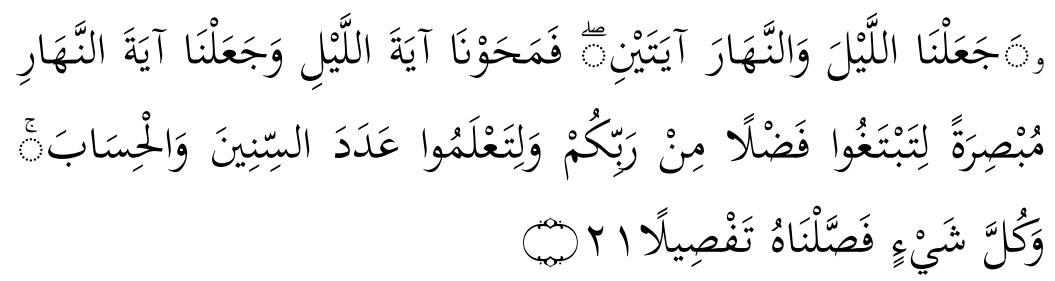

Artinya: "Dan Kami jadikan malam dan siang sebagai dua tanda, lalu Kami hapuskan tanda malam dan Kami jadikan tanda siang itu terang, agar kamu mencari kurnia dari Tuhanmu, dan supaya kamu mengetahui bilangan tahun-tahun dan perhitungan. dan segala sesuatu telah Kami terangkan dengan jelas." (QS. al-Isrâ [17]: 12)

Rezeki diistilahkan dalam al-Qur'an dengan karunia Allah SWT (Mardani, 2011: 5). Ayat di atas menjelaskan tentang anjuran untuk bekerja mencari rezeki yang telah Allah sediakan di atas muka bumi ini. 
Allah SWT berfirman dalam QS. an-Nisâ ayat 29 tentang prinsip yang penting diperhatikan dalam masalah ekonomi dan bisnis yakni:

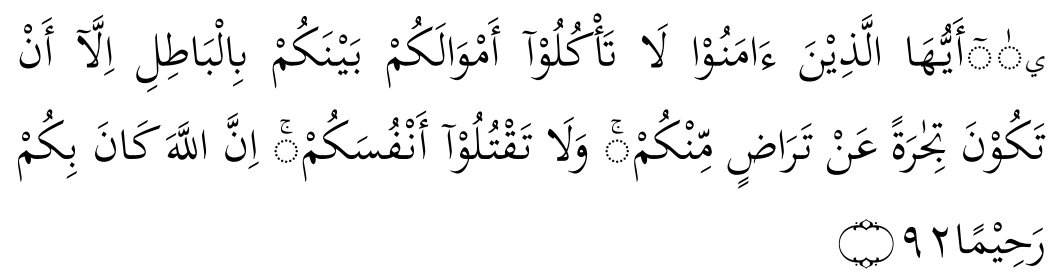

Artinya: "Hai orang-orang yang beriman, janganlah kamu saling memakan harta sesamamu dengan jalan yang batil, kecuali dengan jalan perniagaan yang Berlaku dengan suka sama-suka di antara kamu. dan janganlah kamu membunuh dirimu; Sesungguhnya Allah adalah Maha Penyayang kepadamu." (QS. an-Nisâ [4]: 29)

Pada ayat lain Allah SWT berfirman dalam QS. al-Baqarah ayat 278-279 yakni:

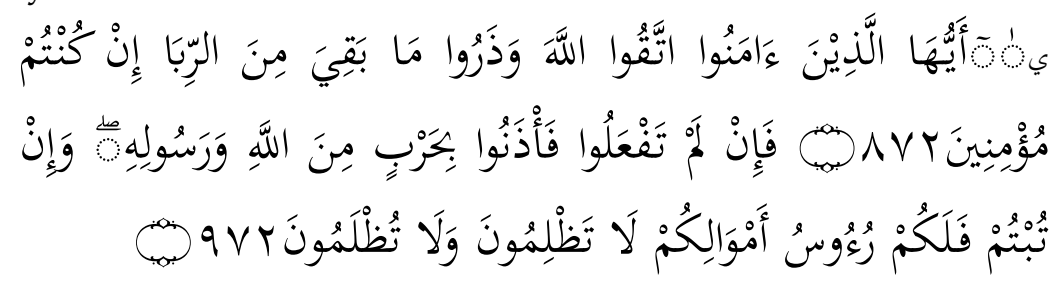

Artinya: "Hai orang-orang yang beriman, bertakwalah kepada Allah dan tinggalkan sisa riba (yang belum dipungut) jika kamu orang-orang yang beriman(278). Maka jika kamu tidak mengerjakan (meninggalkan sisa riba), Maka ketahuilah, bahwa Allah dan RasulNya akan memerangimu. dan jika kamu bertaubat (dari pengambilan riba), Maka bagimu pokok hartamu; kamu tidak Menganiaya dan tidak (pula) dianiaya(279)." (QS. al-Baqarah [2]: 278-279)

Kedua ayat di atas menenjelaskan dua prinsip penting dan mendasar dalam bertransaksi keuangan, yakni prinsip suka sama suka/rela sama rela/saling ridha (an-Nisâ [4]: 29) dan prinisp tidak menzhalimi dan dizhalimi (al-Baqarah [2]: 278-279). Prinsip rela sama rela berarti pelaku ekonomi melakukan transaksi dengan hati yang ikhlas tanpa paksaan. Kemudian prinisp rela sama rela ini berlanjut 
dengan prinsip tidak menzhalimi dan dizhalimi yang berarti pelaku ekonomi menjunjung tinggi keadilan dan salah satu bentuknya adalah meninggalkan praktik riba.

Pada setiap aktivitas ekonomi, tidak lepas dari aturan syariat terhadapnya yang berkaitan dengan status sah dan bathil, halal dan haram atau boleh dan tidak boleh. Ini menunjukkan betapa pentingnya mempelajari dan memahami tata aturan (syariat) dalam muamalah atau aktivitas ekonomi dan bisnis. Dalam konteks muamalah maka sangat utama dan penting memperhatikan aspek halal dan haram dan pada aspek keharaman terdapat haram li zatihi (haram karena zatnya) dan haram li ghairihi (haram bukan karena zatnya, tetapi karena cara mendapatkannya) yang diperlu diketahui dan dipahami secara mendalam agar tidak jatuh pada transaksi terlarang. Apalagi melihat perkembangan zaman dengan arus yang dinamis menghadirkan banyak produk dan jasa keuangan baru yang muncul dalam perekonomian modern. Dalam praktik jual beli muncul istilah reseller, dropship, pre order, stokis, dan lain sebagainya. Produk keuangan kontemporer hadir seperti e-money, e-wallet, foreign exchange, crowdfunding, saham, sukuk, giro, deposito, cessie, fidusia, sistem penjaminan model personal guarantee, corporate guarantee dan bank guarantee. Lalu ada jasa transportasi online dan delivery semisal gojek dan Grab dengan berbagai fiturnya yang menghiasi perputaran roda ekonomi.

Saat ini pula interaksi ekonomi tidak lagi sebatas interaksi personal, namun sudah beranjak kepada interaksi institusional dengan hadirnya berbagai lembaga keuangan di tengah masyarakat seperti bank, asuransi, pegadaian, koperasi, perusahaan modal ventura, perusahaan reksadana dan lain-lain. Komprehensifnya ajaran Islam telah menunjukkan syariat yang mengatur masalah ritual dan interaksi sosial ekonomi. Dengan hadirnya beragam produk dan jasa keuangan di tengah masyarakat dalam perekonomian modern, maka kedudukan fikih muamalah sangatlah penting untuk dipelajari agar dapat merespons ekonomi dan keuangan kontemporer dengan tetap memperhatikan prinsip syariah yang mendasarinya sehingga tidak terjerumus pada transaksi terlarang.

\footnotetext{
URGENSI MEMPELAJARI FIKIH MUAMALAH DALAM MERESPON

36 EKONOMI DAN KEUANGAN KONTEMPORER

Muhammad Syarif Hidayatullah
} 


\section{B. METODE PENELITIAN}

Jenis penelitian yang digunakan penulis adalah penelitian kualitatif dengan mengaplikasikan penelitian kepustakaan (library research). Data yang digali dalam penelitian ini terkait urgensi mempelajari fikih muamalah dalam upaya merespons perkembangan ekonomi dan keuangan di tengah masyarakat dengan hadirnya berbagai produk keuangan dan jasa kontemporer. Teknik pengumpulan data melalui studi kepustakaan (library study) dengan melakukan penelusuran dan penelaahan terhadap karya tulis ilmiah seperti buku dan artikel baik tulisan bersifat online maupun offline yang kemudian dianalisis dengan analisis yang yang bersikat deskriptif.

\section{HASIL DAN PEMBAHASAN}

\section{Peta Kajian dalam Kerangka Dasar Ajaran Islam}

Kerangka secara bahasa menurut Kamus Besar Bahasa Indonesia (KBBI) berarti garis rancangan (Pusat Bahasa Departemen Pendidikan Nasional, 2008: 696). Kerangka dasar berarti rancangan yang sifatnya prinsipil/asasi (suatu hal yang fundamental/mendasar). Dengan demikian, kerangka dasar ajaran Islam maksudnya adalah garis besar rancangan ajaran Islam yang sifatnya mendasar, atau yang mendasari semua nilai dan konsep yang ada dalam ajaran Islam. kerangka dasar ajaran Islam meliputi tiga konsep kajian pokok, yaitu akidah, syariah, dan akhlak. Tiga kerangka dasar ajaran Islam ini sering juga disebut dengan tiga ruang lingkup pokok ajaran Islam atau trilogi ajaran Islam.

Pada dasarnya, makna syariah dalam arti luas mencakup seluruh petunjuk agama Islam, baik yang menyangkut akidah, ibadah, muamalah, etika dan hukum-hukum yang mengatur seluruh aspek kehidupan manusia. Namun seiring berjalannya waktu, pengertian syariah sendiri mengalami perubahan dalam arti penyempitan. Pada masa perkembangan ilmu agama Islam abad kedua dan ketiga, masalah akidah mempunyai nama tersendiri, yaitu ushuluddin, sementara masalah etika dibahas dalam ilmu tersendiri yakni ilmu ilmu akhlak. Karena itu istilah syariah sendiri dalam pengertiannya mengalami historical continuity yang pada akhirnya menjadi menyempit, khusus mengenai hukum yang perbuatan manusia. Dalam arti ini, kata syariat Islam identik dengan kata hukum dalam arti teksteks hukum dalam al Quran dan sunnah nabi (Halim, 2008: 68).

\section{URGENSI MEMPELAJARI FIKIH MUAMALAH DALAM}


Islam adalah akidah, syariah dan akhlak. Ketiganya menjadi satu kesatuan tak terpisahkan, satu sama lainnya saling terkait dan saling menyempurnakan. Tanpa akidah, maka syariat takkan tegak dan akhlak takkan mulia, tanpa syariat, maka akidah takkan kokoh dan akhlak takkan terjaga dan tanpa akhlak, maka akidah takkan kuat dan syariah takkan terlaksana. Meskipun demikian, ketiganya dapat dibedakan satu sama lain. Akidah sebagai konsep atau sistem keyakinan yang bermuatan elemen-elemen dasar iman, menggambarkan sumber dan hakikat keberadaan agama. Syariah sebagai konsep atau sistem hukum berisi peraturan yang menggambarkan fungsi agama. Sedangkan akhlak sebagai sistem nilai etika menggambarkan arah dan tujuan yang hendak dicapai oleh agama. Tiga kerangka dasar ini pula merujuk kepada konsep iman, islam dan ihsan. Akidah merujuk kepada konsep iman dalam formulasi rukun iman yang enam, yaitu iman kepada Allah, Malaikat-Nya, Kitabkitab-Nya, Rasul-rasulnya, Hari Akhir, dan Qadha dan Qadar-Nya. Syariah merujuk kepada konsep islam dalam formulasi rukun Islam yang lima, bersaksi bahwa tidak ada Tuhan selain Allah dan Muhammad adalah utusan-Nya, mendirikan shalat, menunaikan zakat, melaksanakan puasa di bulan Ramadhan, dan haji ke Baitullah bagi yang mampu, selain rukun Islam, lebih luas lagi syariah merupakan aturan hukum Allah SWT yang mencakup masalah ritual maupun interaksi sosial. Akhlak perwujudan dari konsep ihsan dan Nabi Muhammad SAW adalah sebaik-baik contoh atau suri tauladan (uswatun hasanah) dengan akhlak yang begitu mulia (akhlaqul karimah).

Ketiga kerangka dasar tersebut harus terintegrasi dalam diri seorang Muslim. Integrasi ketiga komponen tersebut dalam ajaran Islam ibarat sebuah pohon, akarnya adalah akidah, sementara batang, dahan, dan daunnya adalah syariah, sedangkan bunga yang mekar atau buahnya adalah akhlak. Dalam perspektif sebagai sebuah disiplin ilmu, maka pembahasan akidah ada dalam rumusan ilmu tauhid/kalam/ushuluddin, pembahasan syariah dalam rumusan ilmu fikih, dan pembahasan akhlak dan penyucian jiwa dalam rumusan ilmu tasawuf.

\footnotetext{
URGENSI MEMPELAJARI FIKIH MUAMALAH DALAM MERESPON

38 EKONOMI DAN KEUANGAN KONTEMPORER

Muhammad Syarif Hidayatullah
} 


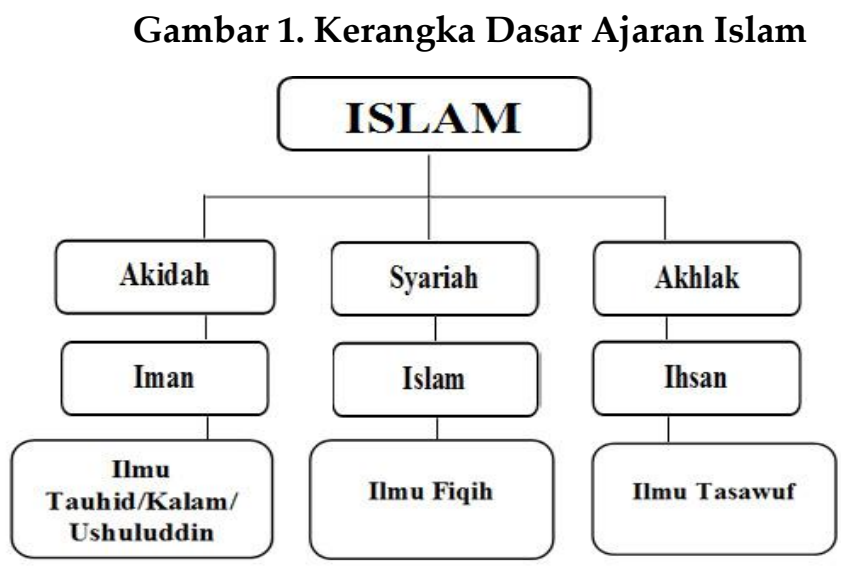

\section{Ruang Lingkup Kajian Fikih Muamalah}

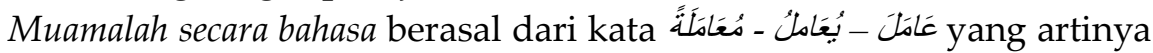
saling bertindak, saling berbuat, dan saling mengamalkan (Munawwir, 1997:1068). Sedangkan secara istilah dapat dibagi kedalam dua pengertian, yakni pengertian dalam arti luas dan pengertian dalam arti sempit.

Muamalah dalam arti luas, Wahbah az-Zuhailî mendefiniskan muamalah sebagai berikut (az Zuhailî, 1985: 19):

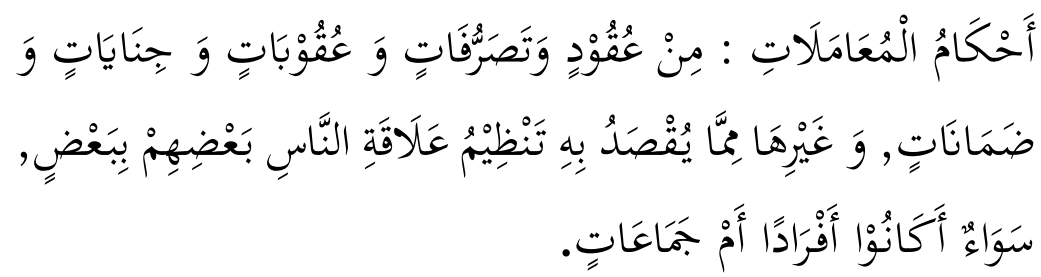

Artinya: "Hukum Muamalah: Kontrak, perilaku, hukuman, tindak pidana, penjaminan, dan hal-hal lain yang dimaksudkan untuk mengatur hubungan manusia satu sama lain, baik itu perorangan atau kelompok."

Lalu Abdul Sattar Fathullah Sa'id mendefinisikan sebagai berikut (Sa'id, 1402: 12): 


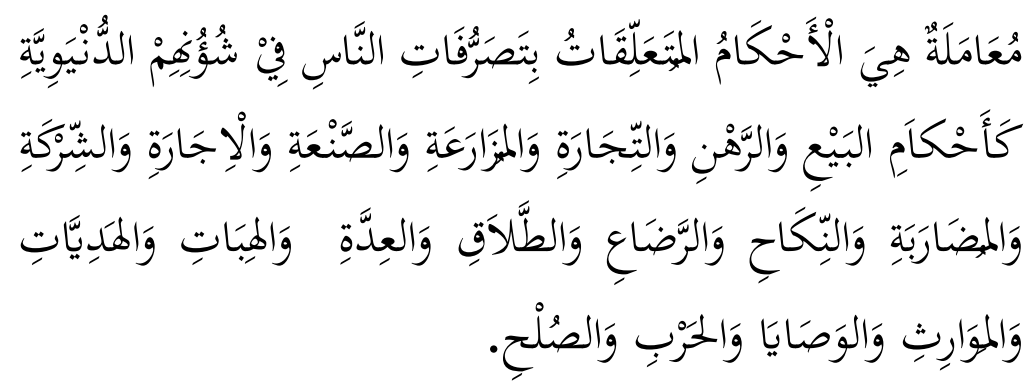

Artinya: "Muamalah adalah ketentuan hukum yang berkaitan dengan perilaku manusia dalam urusan duniawi, seperti ketentuan hukum tentang jual beli, gadai, perniagaan, pertanian, pengerjaan (pembuatan sesuatu), sewa-menyewa, perserikatan, kerja sama bagi hasil, pernikahan, penyusuan, talak, iddah, hibah, hadiah, warisan, wasiat, perang dan damai."

Dengan demikian, muamalah dalam arti luas dapat didefinisikan sebagai aturan-aturan hukum Allah terhadap manusia berkaitan dengan urusan duniawi dalam interaksi sosial. Maka dari itu dalam pengertian ini, fikih muamalah mencakup semua peraturan di luar ibadah. Sedangkan muamalah dalam arti sempit, seperti yang disampaikan oleh Muhammad al-Khudharî Bik sebagai berikut (Bik, 2018: 61):

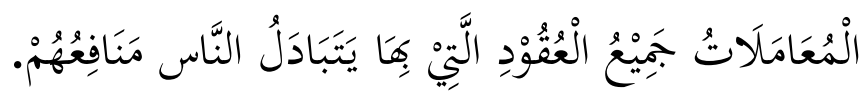

Artinya: "Muamalah adalah semua akad yang membolehkan manusia saling menukar manfaatnya."

Lalu definisi dari Musthafâ Ahmad az Zarqâ sebagai berikut (Zarqâ, 2004: 66):

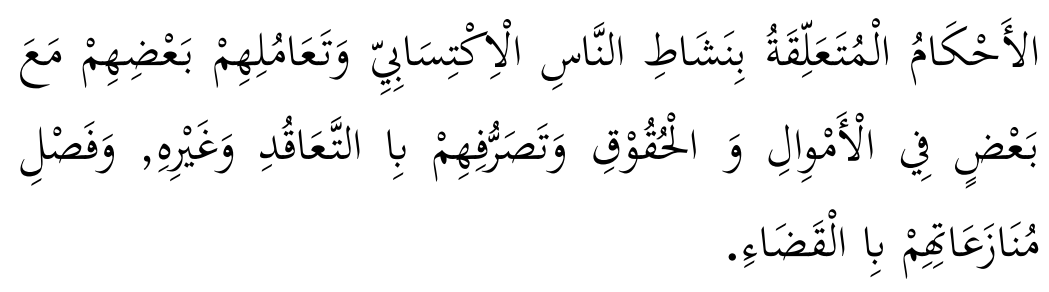

Artinya: "Ketentuan hukum terkait dengan perbuatan dan hubunganhubungan sesama manusia mengenai harta kekayaan, hak-hak dan 
perilaku mereka melalui kontrak dan lainnya, serta penyelesaian sengketa melalui pengadilan."

Muamalah dalam arti sempit memiliki arti aturan-aturan hukum Allah yang yang mengatur hubungan manusia dengan manusia dalam kaitannya dengan cara memperoleh dan mengembangkan harta benda. Maka dalam arti sempit, fikih muamalah dimaknai sebagai hukum ekonomi syariah.

Istilah muamalah sebenarnya memiliki cakupan yang luas yakni pada hubungan antar manusia atau mencakup seluruh interaksi sosial antar satu dengan yang lainnya (muamalah dalam arti luas). Namun dalam perkembangannya, istilah muamalah mengalami pemaknaan yang lebih sempit yaitu mengarah pada ketentuan hukum permasalahan mu'âmalah mâlîyyah (transaksi keuangan) atau iqtishâdiyyah (ekonomi), maka dari itu saat ini fikih muamalah disebut juga dengan istilah hukum ekonomi syariah. Sedangkan permasalahan lainnya yang sebenarnya juga masuk dalam muamalah, mulai dibahas dalam disiplin kajian ilmu keislaman yang berbeda dengan nama tersendiri seperti masalah pernikahan, iddah, talak, perceraian dikenal pembahasannya dalam fikih munâkahah atau disebut pula ahwal asySyaikhsiyah, hukum pidana dibahas dalam fikih jinâyah, sedangkan politik dan ketatanegaraan masuk dalam disiplin kajian fikih siyâsah.

Gambar 2. Fikih Islam

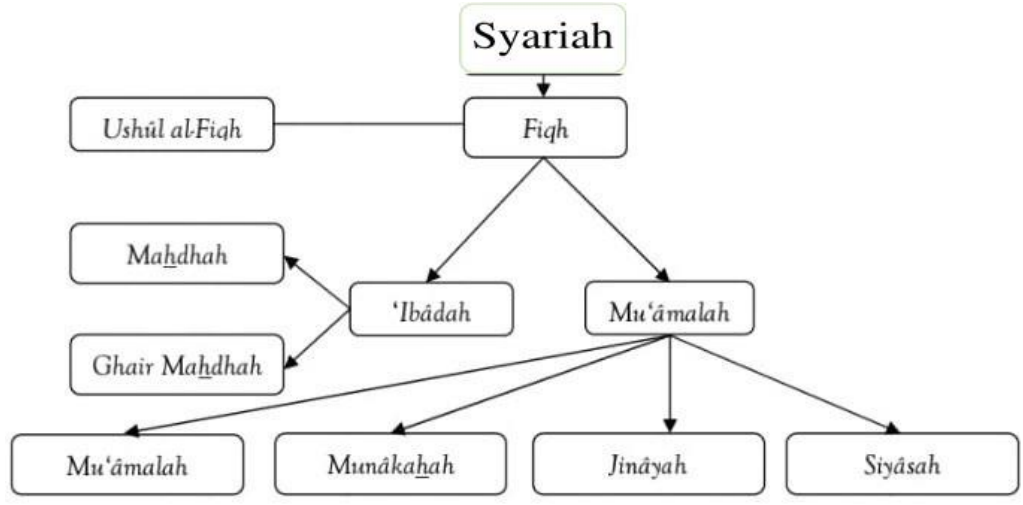

Ruang lingkup fikih muamalah (hukum ekonomi syariah) menurut Ali Fikri mencakup muamalah mâdiyah dan muamalah adabiyah. Kedua cakupan ini dapat dijelaskan sebagai berikut:

\section{URGENSI MEMPELAJARI FIKIH MUAMALAH DALAM} MERESPON EKONOMI DAN KEUANGAN KONTEMPORER 
1. Muamalah mâdiyah yaitu suatu pergaulan yang terjadi antar manusia yang berkaitan dengan materi atau yang porosnya berada di atas sesuatu yang bersifat materil seperti jual beli barang dan jasa dan yang merupakan pertukaran harta benda dan kemanfaatan antara manusia melalui akad atau transaksi (Fikri, 1939: 7). Muamalah mâdiyah meliputi jual beli (bai'), kerja sama (syirkah), bagi hasil (mudhârabah), pinjam-meminjam (Âriyah), utang-piutang (qardh), penitipan barang (wadi'ah), sewa-menyewa/upahmengupah (ijârah), pertukaran uang (sharf), sayembara (ju'âlah), akad-akad jasa, filantropi dan masalah ekonomi kontemporer seperti bank syariah, koperasi syariah, asuransi syariah, pasar modal syariah, E-Commerce, E-Money, E-Wallet dan lain sebagainya.

2. Muamalah adabiyah, yaitu suatu pergaulan antar manusia yang penekanannya kepada perilaku, sikap dan tindakan yang bersumber dari lisan dan anggota badan yang dasarnya adalah kesopanan dan berperadaban supaya bisa tercipta masyarakat madani (Fikri, 1939: 9) Muamalah adabiyah meliputi masalah ijab kabul, keridhaan, keadilan, kejujuran, unsur penipuan, penimbunan, pemalsuan dan lain sebagainya.

Pada tataran praktik, muamalah mâdiyah dan adabiyah tidak dapat dipisahkan, sebab kedua hal tersebut merupakan satu-kesatuan. Maka dari itu pembagian ini hanyalah dalam kepentingan teoritis saja dalam mengenali aspeknya (Syafe'i, 2001: 17).

Muamalah erat kaitannya dengan perkara akad. Akad merupakan perikatan atau pertalian antara dua pihak yang timbul karena kesesuaian kehendak diantara keduanya melalui ijab dan kabul yang menjadi pertanda bahwa kedua belah pihak telah sepakat dan ridha terhadap perjanjian yang dilakukan (Nafi, 2017: 37) Melihat eksistensi akad dalam muamalah, maka dapat diklasifikan menjadi akad tijârah (komersial) dan tabarru' (sosial). Kedua jenis akad tersebut dapat dilihat pada gambar berikut: 


\section{Gambar 3. Akad dalam Aktivitas Ekonomi}

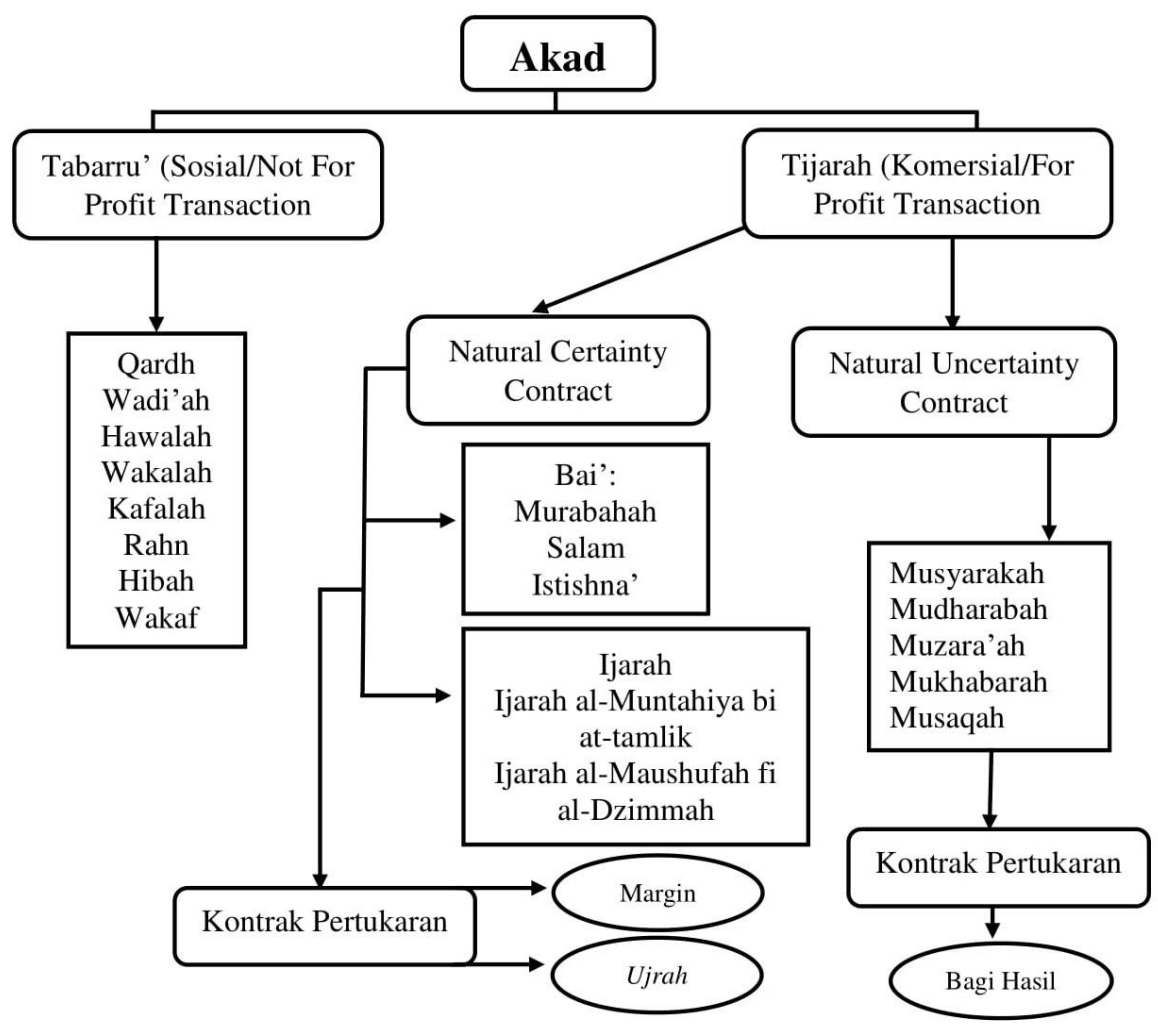

Kaidah fikih yang berlaku dalam perkara muamalah yakni (Azhari, 2014: 156):

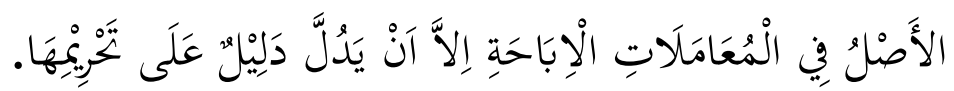

Artinya: "Hukum asal dalam muamalah adalah boleh dilakukan, terkecuali ada dalil yang mengharamkannya."

Oleh karena itu, ijtihad dan inovasi perlu dilakukan. Ijtihad tidak boleh berhenti supaya semua pertanyaan terjawab dan aturan syariatnya. Dengan begitu, syariat ini telah menjawab dan mengatur semua bisnis dan keuangan di setiap ruang dan waktu (Sahroni, 2019: 282-283). Hukum asal muamalah membuka ruang untuk terjadinya kreasi, inovasi dan modifikasi produk dan jasa keuangan dalam 
aktivitas ekonomi menyeseuaikan pada perkembangan zaman yang ada, namun hal ini bukan berarti dapat dengan bebas tanpa aturan menggunakannya, karena perlu identifikasi unsur transaksi di dalamnya dengan memperhatikan aspek sah-batil dan halal-haram dalam dimensi syariah.

\section{Urgensi Mempelajari Fikih Muamalah dalam Merespons Ekonomi dan Keuangan Kontemporer}

Ajaran Islam tidaklah terbatas pada perkara ibadah. Sesuatu yang keliru apabila syariat islam hanya dipandang pada segi ibadah saja. Sebab syariat Islam itu sangat luas, lengkap dan sempurna, aturan hukum di dalamnya selain mengatur persoalan penghambaan manusia kepada Tuhan, juga mengatur persoalan hubungan interaksional antar manusia yang menunjukkan eksistensi manusia sebagia makhluk sosial. Terdapat rambu-rambu yang menjadi batasan dalam perilaku manusia untuk melakukan interaksi sosial termasuk pada aktivitas ekonomi dan bisnis.

Menurut Muhammad Syafi'i Antonio sebagaimana dikutip oleh M. Arfin Hamid dalam bukunya Membumikan Ekonomi Syariah di Indonesia: Perspektif Sosioyuridis, menyatakan bahwa Islam seringkali disalahpahami sebagai agama ritual bukan sebagai sebuah sistem yang komprehensif dan mencakup seluruh aspek kehidupanm termasuk permasalahan dalam pembangunan ekonomi. Ini merupakan pandangan keliru yang semestinya diluruskan. Sebab Islam sebagai ajaran yang komprehensif dan universal mengandung pengertian sebagai syariah yang mengatur dan merangkum seluruh aspek kehidupan, baik perkara ibadah (ritual) maupun muamalah (interaksi sosial). Ibadah diperlukan untuk menjaga ketaatan dan keharmonisan hubungan manusia dengan Allah SWT (habluminallah) dan ibadah juga merupakan sarana untuk mengingatkan secara berkelanjutan tugas manusia sebagai khalifah dimuka bumi. Sedangkan muamalah merupakan rules of game atau aturan main manusia dalam hubungannya antar sesama (habluminannâs) pada kehidupannya sebagai makhluk sosial (Hamid, 2008: 306).

Persepsi Islam sebagai agama yang mengatur perkara ritual dan tidak berperan aktif dalam pembangunan dan pengembangan ekonomi inilah yang membuat umat Islam mulai melupakan fikih muamalah dalam ta'lim-nya. Kajian tasawuf berupa tazkiayatun nafs (penyucian

\footnotetext{
URGENSI MEMPELAJARI FIKIH MUAMALAH DALAM MERESPON

44 EKONOMI DAN KEUANGAN KONTEMPORER

Muhammad Syarif Hidayatullah
} 
jiwa) dan kajian fikih ibadah menjadi fokus utama yang diusahakan sebaik-baiknya, namun disisi lain kompetensi fikih muamalah menjadi seadanya. Persepsi keliru akan eksistensi ekonomi dalam komprehensifnya ajaran Islam, pada akhirnya membuat sebagian umat Islam menutup mata dan memupuk ketidakpedulian terhadap aktivitas ekonomi yang dilakukan apakah sesuai dengan prinsip syariah atau tidak.

Ekonomi syariah adalah bagian integral dari sistem Islam yang sempurna. Jika ekonomi konvensional dengan sebab situasi kelahirannya terjadi sekulerisasi dengan pemisahan antara ekonomi dana agama. Maka keistimewaan terpenting ekonomi syariah atau ekonomi Islam adalah keterkaitannya secara sempurna dengan Islam itu sendiri, yaitu akidah dan syariah ('Assal \& Karim, 1977: 17-18). Ekonomi syariah menjadi bagian dari Islam yang sempurna, maka tidak mungkin memisahkannya dari sistem aturan Islam yang lain yakni akidah, ibadah dan akhlak (Qal'ah, 2000: 54).

Husîn Syahâtah menyatakan bahwa fikih muamalah (fikih ekonomi syariah) memiliki kedudukan yang sangat penting dalam Islam. Tidak ada manusia yang lepas dari aktivitas ekonomi dalam menjalani kehidupannya. Oleh sebab itu hukum mempelajari fikih muamalah adalah fardhu 'ain bagi setiap muslim. Seorang muslim memiliki kewajiban untuk memahami bagaimana muamalahnya sebagai kepatuhan kepada syariat yang Allah tetapkan. Apabila tidak memahami perkara muamalah ini, maka tanpa disadari bisa terjerumus kepada sesuatu yang diharamkan maupun syubhat. Seorang Muslim yang bertaqwa kepada Allah SWT, sudah seharusnya berusaha keras menjadikan muamalahnya sebagai amal shaleh dan dilakukan ikhlas untuk Allah semata.Memahami hukum muamalah wajib bagi setiap muslim, namun untuk menjadi pakar (ahli ilmu/ulama) dalam bidang ini hukumnya fardhu kifayah (Syahâtah, t.t.).

Fikih Muamalah diperoleh melalui penelusuran langsung terhadap al-Qur'an dan Hadits oleh para para fukaha. Melalui kaidahkaidah ushuliyah, mereka merumuskan beberapa aturan yang harus dipraktekkan dalam kehidupan ekonomi umat. Dalam epistemologinya, setelah al-Qur'an dan hadits, terdapat ijtihad dengan menggunakan rasio atau akal. Ijtihad merupakan upaya penggunaaan akal untuk memformulasikan dan menghasilkan produk hukum 
(Iskandar \& Aqbar, 2019: 95-96). Maqâshid asy-Syarî'ah pula menjadi instrumen penting dalam kajian ekonomi dan keuangan kontemporer. Karena maqâshid asy-Syarî'ah relevansi dalam pemenuhan ijtihad ekonomi syariah dalam kategori dharuriyat (primer), hajiyat (sekunder) dan tahsiniyat (tersier) (Arifin, 2015: 96). Untuk dapat menjawab persoalan umat dalam masalah ekonomi dan keuangan kontemporer dan menyikapi interaksi sosial ekonomi modern dengan tepat sasaran mewujudkan iklim ekonomi syariah yang membawa kemaslahatan umat, maka para ulama ahli fikih muamalah perlu pengkajian hukum progresif, responsif dan solutif dengan mengkorelasikan antara ushûl figh, qawâ'id fihqhiyyah dan maqâshid asysyarî'ah dalam ijtihad memformulasikan fikih muamalah kontemporer.

Para ulama bersepakat (konsensus) bahwa muamalah adalah kebutuhan umat manusia yang sangat penting dan umat Islam mutlak mengetahui serta memahami hukum muamalah (Sa'id, 1402: 14). Ekonomi yang didasarkan pada syariat Islam, maka ini merupakan bentuk ketaatan kepada Allah SWT Setiap ketaatan kepada Allah merupakan jalan ibadah (ketaqwaan), maka menerapkan sistem ekonomi syariah adalah meniti jalan ibadah (ketaqwaan) kepada Allah SWT (Qal'ah, 2000: 55).

Umar bin Khattab pernah mengeluarkan perintah (at Tirmidzî, 1998: 615):

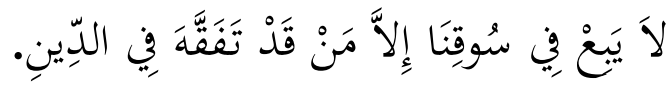

Artinya: "Janganlah ada seseorang yang berjualan dipasar kami ini, kecuali jika ia telah mengerti ilmu agama (muamalah/halal dan haram dalam jual beli)."

Dalam redaksi lain Umar bin Khattab pula berkata (asy Syarbînî, 1994: 364):

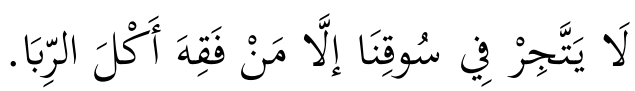

Artinya: "Janganlah seseorang berdagang di pasar kami sampai dia paham betul mengenai seluk beluk riba."

Perintah Umar bin Khattab ra. diatas menunjukkan betapa pentingnya mengerti ilmu agama terkait persoalan muamalah, sebab

\footnotetext{
URGENSI MEMPELAJARI FIKIH MUAMALAH DALAM MERESPON

46 EKONOMI DAN KEUANGAN KONTEMPORER

Muhammad Syarif Hidayatullah
} 
pasar merupakan sektor perekonomian yang didalamnya berlangsung transaksi keuangan antara produsen dan konsumen

Selaras dengan perkataan Umar bin Khattab, Ali bin Abi Thalib menyatakan (asy Syarbînî, 1994: 364):

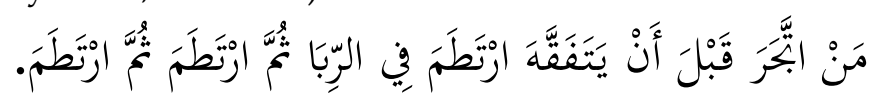

Artinya: "Barangsiapa yang berdagang namun belum memahami ilmu agama, maka dia pasti akan terjerumus dalam riba, kemudian dia akan terjerumus ke dalamnya dan terus menerus terjerumus."

Abu Laits pula menuturkan (Halabî, 1973: 359):

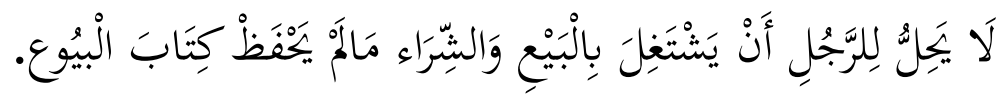

Artinya: "Seorang laki-laki tidak halal melakukan akad jual beli selagi dia belum menguasai bab fikih jual-beli."

Muhammad bin Hasan juga berkata (Halabî, 1973: 359):

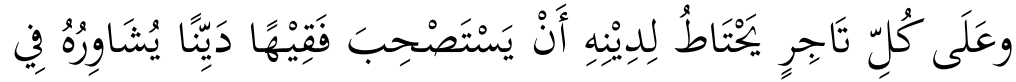

Artinya: "Setiap pedagang yang kuat memegang agama wajib dia minta didampingi oleh ahli fiqih muamalat yang taqwa agar si pedagang dapat bermusyawarah dengan ahli fikih tersebut tentang transaksi yang dilakukan."

Perkataan Sahabat (Umar bin Khattab dan Ali bin Abi Thalib) dan nasehat Ulama (Abu Laits dan Muhammad bin Hasan) di atas menunjukkan betapa pentingnya mempelajari dan memahami tata aturan hukum (syariat) dalam muamalah atau aktivitas ekonomi dan bisnis. Namun, dengan ditelantarkannya pembelajaran fikih muamalah berdampak pada sikap acuh pada halal dan haram atau sah dan bathilnya suatu transaksi keuangan yang dilakukan, padahal setiap harinya kita tidak lepas dari aktivitas ekonomi. Hal ini akhirnya memunculkan suatu fenomena di masyarakat yakni religiusitas yang parsial dengan adanya upaya maksimal memperbaiki ibadah dan batiniyah, namun upaya minimal memperbaiki muamalah. 
Di satu sisi, masjid-masjid dimakmurkan dengan shalat berjamaah, i'tikaf para jamaahnya, buka puasa bersama baik puasa fardhu maupun sunnah dan diadakannya majelis taklim yang dipenuhi oleh masyarakat, namun disisi lain, praktik riba semakin marak dan bertebaran dimana-mana. Praktik riba seperti telah menjadi unsur terlarang yang dianggap biasa di tengah masyarakat, baik itu disalurkan secara individual dengan eksistensi para rentenir, maupun disalurkan secara institusional dengan hadirnya banyak lembaga keuangan ribawi yang beroperasi dengan pinjaman uang berbunganya. Bahkan dengan tawaran kemudahan dan kecepatan akses berupa slogan "1 jam cair" semakin membuat masyarakat tergiur untuk melakukan utang-piutang ribawi.

Padahal riba merupakan kegiatan terlarang (dosa besar) yang diancam perang oleh Allah dan Rasulullah yang seharusnya tidak dianggap remeh. Allah SWT berfirman dalam QS. al-Baqarah ayat 279 sebagai berikut:

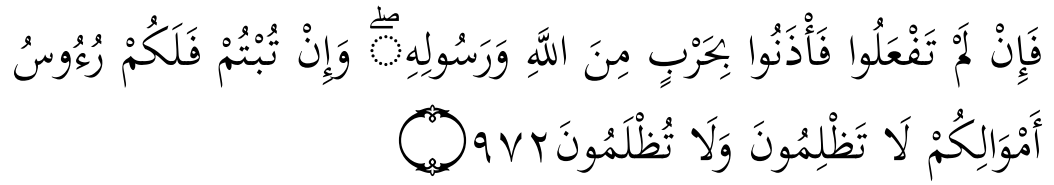

Artinya: "Maka jika kamu tidak mengerjakan (meninggalkan sisa riba), Maka ketahuilah, bahwa Allah dan Rasul-Nya akan memerangimu. dan jika kamu bertaubat (dari pengambilan riba), Maka bagimu pokok hartamu; kamu tidak Menganiaya dan tidak (pula) dianiaya."(QS. al-Baqarah [2]: 279)

Kemudian dalam sebuah hadits yang menerangkan dosa riba, Rasulullah SAW bersabda (Qazwînî, 2012: 80):

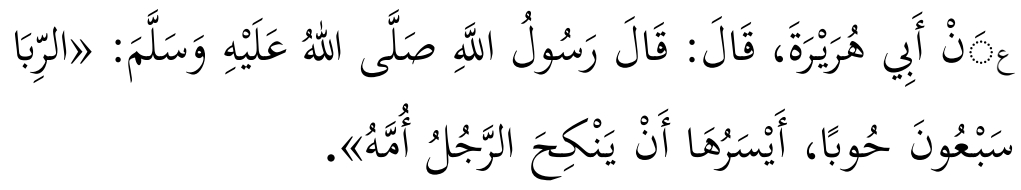

Artinya: Dari Abu Hurairah ra., ia berkata, Rasulullah bersabda: "Riba adalah tujuh puluh dosa; dosanya yang paling ringan adalah (sama dengan) dosa orang yang berzina dengan ibunya." (HR. Ibnu Majah)

Dalam doktrin hukum ekonomi syariah (fikih muamalah) dikenal kaidah fikih yang menjadi dasar secara umum dari kegiatan muamalah, yakni (Azhari, 2014: 156): 


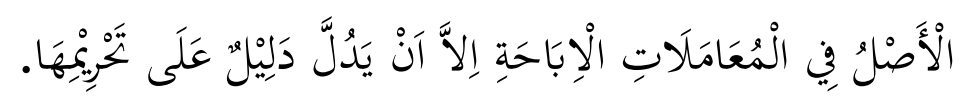

Artinya: "Hukum asal dalam muamalah adalah boleh dilakukan, terkecuali ada dalil yang mengharamkannya."

Maka dari itu kita penting dan perlu mengidentifikasi dulu aktivitas ekonomi yang kita lakukan. Kategori haram dapat diklasifikasikan menjadi dua macam, yakni haram lidzatihi dan haram lighairihi. Haram lidzatihi adalah segala sesuatu yang diharamkan dengan sebab zatnya atau karena memang zatnya haram, sedangkan haram lighairihi adalah bukan haram karena zatnya, melainya haram karena hal lain yang membuatnya haram semisal cara mendapatkannya. Haram ligahirihi dalam masalah transaksi ekonomi dan keuangan, contohnya seperti riba (fadhl dan nasi'ah), gharar (ketidakjelasan), maysir (perjudian), najsy (jual beli kecohan), ihtikar (penimbunan), tadlis (penipuan) dan risywah (suap) (Hidayatullah, 2017: 23).

Berdasarkan kaidah dasar muamalah sebelumnya, maka kita berpeluang untuk memberikan inovasi terhadap produk ekonomi dan keuangan asalkan tidak bertentangan dengan apa yang diajarkan dalam syariat Islam atau memuat unsur-unsur yang terlarang dalam bermuamalah. Agus Rijal secara umum menyebutkan hal-hal yang dilarang dalam muamalah yakni (Rijal, 2013: 44-45): pertama, komoditas haram dan usaha yang mengarah pada kemaksiatan. Kedua, maysir, yaitu kepemilikan harta tanpa akad yang diperkenankan atau melalui permainan. Ketiga, gharar, yaitu memakai akad, namun tidak jelas atau menyembunyikan fakta. Keempat, riba, yaitu tambahan yang menzalimi. Kelima, bai' mudhthar, yaitu memainkan harga pada saat orang lain membutuhkan. Keenam, ikrâh, yaitu memainkan harga dengan tekanan atau paksaan. Ketujuh, ghabn fâhisy, yaitu menaikkan harga di luar kewajaran. Kedelapan, najsy, yaitu mempermainkan harga dengan berpura-pura atau menggunakan pihak lain sebagai penawar. Kesembilan, ihtikâr, mempermainkan harga dengan cara menimbun. Kesepuluh, ghisy, yaitu menyembunyikan informasi tentang barang atau jasa dengan maksud menjaga harga. Kesebelas, tadlis, yaitu mengambil keuntungan dengan cara mencampur aduk barang yang baik dengan yang tidak baik. 
Syariah dalam ajaran Islam mencakup ibadah dan muamalah. Tidak bisa mengerjakan salah satunya lalu meninggalkan yang lainnya, sebab ibadah dan muamalah terkait laksana satu tubuh dan keduanya satu tujuan pada ketaatan kepada Allah SWT (Ridhwân, 1996: 166). Allah SWT memerintahkan agar kita masuk ke dalam Islam secara kaffah (menyeluruh) bukanlah secara parsial (setengah-setengah). Allah SWT berfirman dalam QS. al-Baqarah ayat 208:

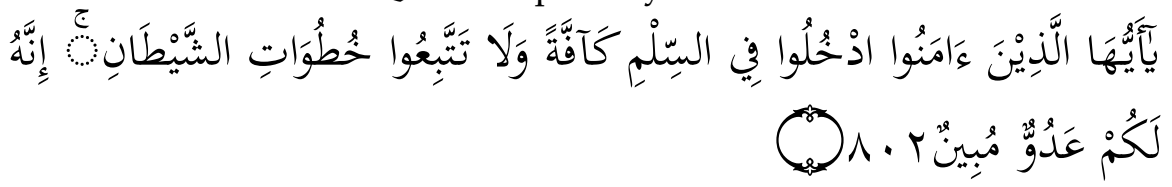

Artinya: "Hai orang-orang yang beriman, masuklah kamu ke dalam Islam keseluruhan, dan janganlah kamu turut langkah-langkah syaitan. Sesungguhnya syaitan itu musuh yang nyata bagimu." (QS. alBaqarah [2]: 208)

Fenomena religiusitas parsial haruslah berevolusi menjadi religiusitas kaffah (total) dengan aspek syariah yang menyentuh persoalan ibadah dan muamalah. Dikarenakan jika ini terus dibiarkan, maka dosa ribapun akan semakin dianggap biasa, praktik pembungaan uang semakin merajalela, dan menjadikan lembaga keuangan ribawi semakin tumbuh kembang di masyarakat sedangkan lembaga keuangan syariah lambat laun akan tersingkir dikarenakan sikap skeptis umat Islam sendiri. Dengan begitu, maka hadirnya lembaga keuangan syariah yang pada hakikatnya adalah untuk menghindarkan masyarakat dari praktik ribawi akan tergerus dengan sikap skeptis umat Islam yang lebih memilih lembaga keuangan ribawi. Ini juga akan berimplikasi pada lembaga keuangan syariah yang mulai melunturkan sisi syariahnya demi mampu bersaing dengan lembaga keuangan ribawi. Padahal, jika memang dalam praktiknya ditemukan adanya penyimpangan oleh lembaga keuangan syariah, maka yang perlu dilakukan adalah memperbaikinya, bukan meninggalkannya lalu memilih kepada lembaga keuangan yang sudah jelas menjalankan operasional bisnis dengan pilar transaksi ribawi.

\section{Pengajian Fikih Muamalah pada Majelis Taklim sebagai Upaya Memasyarakatkan Ekonomi Syariah}

Islam adalah agama dakwah, yaitu seruan dan ajakan kepada keinsyafan, atau usaha mengubah situasi kepada yang lebih baik dan

\footnotetext{
URGENSI MEMPELAJARI FIKIH MUAMALAH DALAM MERESPON

50 EKONOMI DAN KEUANGAN KONTEMPORER

Muhammad Syarif Hidayatullah
} 
sempurna, baik terhadap pribadi maupun masyarakat. Materi dakwah seperti ditunjukkan al-Qur'an berkisar pada tiga masalah pokok, yaitu akidah, akhlak, dan hukum (syariah). Inti dakwah adalah mengajak berbuat al-khair dengan mekanisme menyuruh al-ma'ruf dan melarang berbuat al-munkar berasaskan al-hikmat dan al-mau'izhat al-hasanat, yaitu perkataan yang tegas dan benar yang dapat membedakan antara yang hak dan bathil diiringi dengan perlakuan al-hasanat apabila mereka menentang (Hakim, 201: xii-xiii). Dakwah dalam pelaksanaannya adalah aktivitas sadar manusia baik secara perorangan maupun kelompok sebagai upaya mengaplikasikan ajaran Islam dan mencapai ridha Allah SWT. Aktivitas dakwah apapun konteksnya akan dibutuhkan umat manusia untuk mewujudkan keshalehan umat. Maka dari itu kegiatan dakwah tidak hanya sebagai proses penyampaian ajaran Islam, akan tetapi juga melahirkan kesadaran masyarakat untuk menegakkan tauhid, menumbuhkan persaudaraan, keadilan,dan menciptakan masyarakat yang Islami. Landasan hukum berdakwah di dalam al-Qur'an terdapat dalam QS. al-Mâidah (5): 67 dan QS. an-Nahl (16): 67.

Syiar agama Islam yang dibawa oleh Nabi Muhammad SAW sepanjang alur dakwah yang beliau jalani, penerapan nilai dan aplikasi aktual ekonomi syariah menjadi sesuatu yang begitu diperhatikan mengingat bahwasanya Mekkah adalah daerah perdagangan terbesar saat itu. Dengan perhatian yang besar terhadap persoalan ekonomi ini tidak lain adalah upaya preventif terhadap terjadinya berbagai hal kecurangan dalam aktivitas ekonomi seperti perniagaan yang berlangsung. Sangat banyak hadits-hadits Nabi SAW dengan substansi yang menunjukkan paparan aturan hukum dalam bermuamalah dan juga pengelolaan negara saat nabi berperan sebagai khalifah (Anafarhanah, 2015: 9).

Majelis taklim menjadi salah satu media dakwah yang diminati masyarakat secara umum. Majelis taklim menjadi media yang menjangkau semua kalangan tidak hanya mahasiswa, praktisi, akademisi, pengusaha ataupun para pejabat seperti pembelajaran melalui seminar, workshop, short course dan training, tetapi telah begitu membumi di tengah masyarakat bahkan memiliki fadhilah i'tikaf ketika dilaksanakan di dalam masjid yang memang masjid menjadi pusat pelaksanaan majelis taklim selain rumah pribadi. Majelis taklim sebagai

\section{URGENSI MEMPELAJARI FIKIH MUAMALAH DALAM}


lembaga swadaya dan sarana masyarakat untuk menuntut ilmu agama, masih kurang menaruh perhatian terhadap pengajian fikih muamalah terutama pengajian yang dilaksanakan di masjid. Padahal muamalah menjadi bagian yang tidak terpisahkan dalam kehidupan sehari-hari. Mochammad Arif Budiman dan Mairijani dalam hasil penelitiannya menyatakan bahwa saat ini peran masjid dalam pengembangan ekonomi syariah masih sangat terbatas. Salah satunya adalah karena masih minim kajian ekonomi syariah yang dilaksanakan di masjid (Budiman, 2017: 180). Kemudian M. Asyhad dan Wahyu Agung Handono menyebutkan bahwa tingkat pemahaman masyarakat Indonesia tentang layanan dan produk keuangan syariah masih rendah (Asyhad \& Handono, 2019: 127-128).

Perkembangan ekonomi syariah di Indonesia ikut mempengaruhi hadirnya forum-forum edukasi ekonomi syariah, seperti berbentuk workshop, training, short course, dan seminar. Namun forum-forum ini dilihat jangkauannya masih terbatas kepada kalangan praktisi, civitas akademika (dosen dan mahasiswa), para pengusaha dan pejabat negara, sedangkan masyarakat secara umum masih belum tersentuh dalam kapasitas menyeluruh dan merata. Dengan kondisi seperti itu, maka majelis taklim sebagai forum menuntut ilmu agama yang membumi di masyarakat, menjadi pendekatan edukasi yang dapat menjangkau kalangan masyarakat umum untuk peningkatan literasi ekonomi dan keuangan syariah. Maka dalam kajian fikih, penting untuk mempelajari fikih muamalah untuk dapat melihat perkembangan ekonomi saat ini dengan tetap memperhatikan transaksi yang dilakukan antara sah dan bathil, halal dan haram serta boleh dan tidak boleh, apalagi dengan konsep-konsep produk keuangan kontemporer yang mengalami modifikasi, kreasi dan inovasi yang beranjak dari perputaran roda ekonomi yang dinamis.

Pengembangan pengetahuan dan penanaman pemahaman menjadi langkah awal upaya membumikan ekonomi syariah dan salah satu pendekatan yang merakyat adalah memaksimalkan peran majelis taklim sebagai sarana dakwah ekonomi syariah melalui pengajian fikih muamalah terutama yang bersentuhan dengan ekonomi modern. Oleh karena itu upaya memasyarakatkan ekonomi syariah dan mensyariahkan ekonomi masyarakat merupakan bentuk aktualisasi jihad ekonomi umat Islam. 
Materi pengajian di majelis taklim dalam penelitian lapangan penulis sebelumnya dengan lokalitas daerah Banjarmasin, hasilnya menunjukkan bahwa materi pengajian lebih didominasi pada kajian akhlak tasawuf atau bernuansa tazkiyatun nafs (penyucian jiwa) yang berkaitan dengan aspek batin dan perbaikan akhlak yang berhubungan dengan baik dan buruk. Jika ada pembahasan fikih, maka lebih cendrung kepada pembahasan fikih ibadah (ubudiyah). Untuk pembahasan fikih muamalah (fikih ekonomi syariah) seperti tidak menjadi kajian yang dianggap penting dan sangat diperhatikan, sehingga majelis taklim dengan kajian fikih muamalah hampir tidak di temukan (Hidayatullah, 2020: 37-38).

Materi akhlak tasawuf memang penting dalam pengajian sebagai upaya memperbaiki akhlak membersihkan hati dalam rangka tazkiyatun nafs (penyucian jiwa), namun materi fikih yang mencakup ibadah dan muamalah juga sangat penting untuk dipelajari. Munhammad bin Idrîs asy-Syâfi'î berkata (Syâfi'î, 1985: 66):

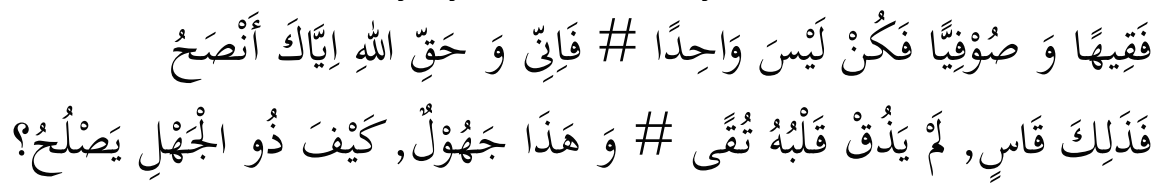

Artinya: "Maka jadilah engkau seseorang yang ahli (paham) fikih dan tasawuf bukan salah satunya saja. Sesungguhnya dengan hak Allah aku memberikan nasehat kepadamu. Ahli fikih (tanpa tasawuf) memiliki hati yang keras dan tidak merasakan lezatnya ketakwaan. Dan ahli tasawuf (tanpa fikih) menjadi bodoh dan bagaimana orang bodoh dapat membawa kemaslahatan (kebaikan)?"

Perkataan asy-Syâfi'î menunjukkan betapa pentingnya ilmu fikih dan tasawuf untuk dipelajari, bukan dengan mengutamakan salah satunya lalu meninggalkan yang lainnya, tetapi kedua-duanya memiliki kedudukan yang sama-sama penting dengan posisi dan porsi masing-masing pada cakupan kajian yang berbeda namun saling melengkapi satu sama lain sehingga terwujud religiusitas lahir-batin yang harmonis menuju jalan yang lurus dan diridai Allah SWT.

Dakwah ekonomi syariah haruslah terus dilakukan dalam bingkai ekonomi rahmatan lil 'âlamîn yang menunjukkan kemaslahatan. Minimnya pengajian di majelis taklim yang menjadikan ekonomi syariah sebagai objek kajian, bukanlah menjadi alasan untuk 
menghentikan dakwah ekonomi syariah. Upaya untuk menyebarluaskan syariat Islam dalam persoalan ekonomi kepada masyarakat perlu secara istiqamah dilaksanakan dan perlu didukung agar pengajian-pengajian fikih muamalah (fikih ekonomi syariah) semakin bertambah. Namun tidak berhenti pada banyaknya majelis taklim fikih muamalah, lebih dari itu perlu bersinergi dengan menumbuhkan minat dan keinginan tahuan masyarakat terhadap pembelajaran fikih muamalah dalam rangka dapat beraktivitas ekonomi yang sejalan dengan prinsip syariah atau tidak bertentangan dengan syariat islam. Jadi perilaku ekonomi yang diaplikasikan adalah aktivitas ekonomi baik itu komersial maupun sosial yang bernaung dibawah naungan mu'âmalah syar'iyyah.

Beberapa kitab yang dapat menjadi opsi atau digunakan untuk referensi kajian kitab di majelis taklim pada persoalan ekonomi syariah dengan kajian fikih muamalah baik klasik maupun kontemporer sebagai upaya membagun paradigma ekonomi syariah di masyarakat dalam merespons ekonomi dan keuangan kontemporer dapat dilihat pada tabel berikut:

\section{Tabel 1.}

Kitab Kajian Ekonomi Syariah

\begin{tabular}{|c|c|}
\hline Penulis & Nama Kitab \\
\hline Wahbah az-Zuhailî & $\begin{array}{l}\text { al-Figh al-Islâmî wa Adillatuh (Bagian Figh } \\
\text { al-Mu'âmalâh) } \\
\text { al-Mu'âmalât al-Mâliyyah al-Mu'âshirah }\end{array}$ \\
\hline Muhammad az-Zuhailî & $\begin{array}{l}\text { al-Mu'tamad fí al-Figh al-Syâfi'î (Juz 3: al- } \\
\text { Mu'âmalât al-Mâliyyah wa al-'Uqûd) }\end{array}$ \\
\hline $\begin{array}{l}\text { Abû Mâlik Kamâl bin as- } \\
\text { Sayyid Sâlim }\end{array}$ & $\begin{array}{l}\text { Shahîh Figh al-Sunnah (Juz 4: Kitâb al- } \\
\text { Buyû́ } \hat{u}^{\prime} \text { ) }\end{array}$ \\
\hline $\begin{array}{lll}\text { Muhammad } & \text { Taqî } & \text { al- } \\
\text { Utsmânî }\end{array}$ & Fiqh al-Buy $\hat{u}^{\prime}$ 'alâ Madzhab al-Arba'ah \\
\hline Ziyâd Ghazâl & $\begin{array}{l}\text { Masyrû' al-Qanûn al-Buyûfíad-Daulah al- } \\
\text { Islâmiyyah }\end{array}$ \\
\hline s-Sabâtin & $\begin{array}{l}\text { al-Buŷu' al-Qadîmah wa al-Mu'âshirah wa } \\
\text { al-Bûrishât al-Mahliyah wa ad-Dauliyah }\end{array}$ \\
\hline $\begin{array}{l}\text { Muhamammad } \\
\text { Syibair }\end{array}$ & $\begin{array}{l}\text { al-Madkhal ila Fiqh al-Mu'âmalât al- } \\
\text { Mâliyyah }\end{array}$ \\
\hline
\end{tabular}




\begin{tabular}{|c|c|}
\hline Penulis & Nama Kitab \\
\hline & $\begin{array}{l}\text { al-Mu'âmalât al-Mâliyyah al-Mu'âshirah fì } \\
\text { al-Figh al-Islâmî }\end{array}$ \\
\hline Yûsuf al-Qaradhâwî & $\begin{array}{l}\text { al-Qawâa'id al-Hâkimah lî Figh al- } \\
\text { Mu'âmalât } \\
\text { Fawấ'id al-Bunûk hiya ar-Ribâ al- } \underline{\text { Harâm }}\end{array}$ \\
\hline Rafic & $\begin{array}{l}\text { Figh al-Mu'âmalât al-Mâliyyah } \\
\text { Buhuts fì Fiqh Mu'âmalât al-Mâliyyah } \\
\text { al-Jâmi' fì Ushûl al-Ribâa } \\
\text { Ribâ al-Qurûdh wa Adillah Tahrîmih }\end{array}$ \\
\hline $\begin{array}{l}\text { Sa'duddîn Muhammad al- } \\
\text { Qibthî }\end{array}$ & al-Mu'âmalâh al-Mâliyyah \\
\hline $\begin{array}{lll}\text { 'Abdul } & \text { Sattâr } & \text { Abû } \\
\text { Ghuddah } & & \\
\end{array}$ & $\begin{array}{l}\text { Buhuts fì al-Mu'âmalât wa al-Asâlîb al- } \\
\text { Mashrifiyyah al-Islâmiyyah }\end{array}$ \\
\hline $\begin{array}{l}\text { 'Alî Muhyîddîn al-Qurrah } \\
\text { Dâghî }\end{array}$ & $\begin{array}{l}\text { Buhn̂ts fì Figh al-Mu'âmalât al-Mâliyyah } \\
\text { al-Mu'âshirah }\end{array}$ \\
\hline 'Ali al-Khafif & Ahkâm al-Mu'âmalât asy-Syar'iyyah \\
\hline Musthafâ Dîb al-Bughâ & Fiqh al-Mu'âwadhât \\
\hline Nâzih Hammâd & $\begin{array}{l}\text { Fî̀ Fiqh al-Mu'âmalât al-Mâliyyah al- } \\
\text { Mashrifiyyah al-Mu'âshirah } \\
\text { Qadhâyâ Fighiiyyah Mu'âshirah fì al-Mâl } \\
\text { wa al-Iqtishâd } \\
\text { al-'Uqû̉ al-Murakkabah fì al-Figh al-Islâmî̀ }\end{array}$ \\
\hline 'Alâuddîn Za'tarî & $\begin{array}{l}\text { Figh al-Mu'âmalât al-Mâliyyah al- } \\
\text { Muqâran }\end{array}$ \\
\hline $\begin{array}{lll}\text { Musthafâ } & \text { Ahmad az- } \\
\text { Zarqâ }\end{array}$ & $\begin{array}{l}\text { al-Madkhal al-Figh al-'Âm } \\
\text { al-'Uqû̀d al-Musammâh }\end{array}$ \\
\hline 'Alî Ahmad as-Sâlûs & $\begin{array}{l}\text { al-Iqtishâd al-Islâmî wa al-Qadhâyâ al- } \\
\text { Fiqhiyyah al-Mu'âshirah }\end{array}$ \\
\hline
\end{tabular}

Pengaplikasian kajian di majelis taklim dapat bertransformasi dari metode monolog ke dialog, maka setiap diadakannya pengajian, setelah materi disampaikan untuk memberikan pemahaman yang mumpuni kepada jamaah dapat dilakukan sesi tanya jawab yang mendeskripsikan dialog antara $d a^{\prime} i$ (subjek dakwah) dengan mad'u 
(objek dakwah) yang memperjelas pembahasan maddah (materi dakwah) dan memaksimalkan wasilah (media dakwah) dengan thariqah (metode dakwah) yang mewujudkan iklim dialog berupa komunikasi dua arah. Hal tersebut dilakukan agar hal-hal yang masih belum jelas atau belum dimengerti oleh jamaah dapat terjawab serta dapat mencegah kekeliruan dan kesalahpahaman dalam menyerap materi pengajian.

Untuk mewujudkan dakwah ekonomi syariah yang bersinergi, maka pengurus masjid dalam mengadakan majelis taklim ekonomi syariah melalui pengajian fikih muamalah dapat menjalin hubungan strategis dan sinergis dengan lembaga fatwa ekonomi syariah yaitu Dewan Syariah Nasional Majelis Ulama Indonesia (DSN-MUI) dan organisasi-organisasi gerakan ekonomi syariah seperti Masyarakat Ekonomi Syariah (MES), Ikatan Ahli Ekonomi Islam (IAEI), Komite Nasional Ekonomi dan Keuangan Syariah (KNEKS), Forum Dosen Ekonomi dan Bisnsi Islam (FORDEBI), Forum Silaturrahim Studi Ekonomi Islam (FOSSEI), Asosiasi Bank Syariah Indonesia (ASBISINDO), Asosiasi Koperasi Syariah Indonesia (ASYKINDO), Komunitas Pengusaha Muslim Indonesia (KPMI), Masyarakat Tanpa Riba (MTR) dan lain sebagainya.

\section{PENUTUP}

Syariat Islam tidak hanya terbatas pada aturan-aturan hukum masalah ibadah yaitu komunikasi vertikal antara manusia dengan Allah (habluminallah), tetapi juga mencakup masalah muamalah yaitu komunikasi antara manusia dengan manusia (habluminannâs). Maka adalah sebuah kekeliruan saat syariat Islam hanya dipahami dalam ruang lingkup aspek ritual, sedangkan aspek interaksi sosial tidak dipedulikan. Kekeliruan ini akan mengakibatkan religiusitas parsial dengan mindset sekuler melalui sekulerisasi ekonomi

Materi fikih muamalah sangat penting untuk dipelajari setiap muslim. Seorang muslim harus mempelajari fikih muamalah agar dapat beraktivitas ekonomi sesuai dengan petunjuk al-Qur'an dan hadits sehingga dapat terhindar dari melakukan transaksi yang haram. Ekonomi bukanlah aktivitas bebas nilai yang dapat dilakukan sebebasbebasnya, namun terdapat rambu-rambu yang harus ditaati yang telah di atur dalam fikih muamalah. Dengan menerapkan ekonomi syariah dalam kehidupan sehari-hari, maka ini adalah bentuk realisasi

\footnotetext{
56 ERGENSI MEMPELAJARI FIKIH MUAMALAH DANOMI DAN KEUANGAN KONTEMPORER

Muhammad Syarif Hidayatullah
} 
ketaqwaan kepada Allah SWT, sebab menjalankan perintahNya dan meninggalkan laranganNya dalam problematika ekonomi. Pemahaman fikih muamalah adalah bekal utama untuk dapat memilah antara sah dan batil atau halal dan haram dalam ekonomi dan keuangan yang berdampak pada terwujudnya perekonomian syariah. Apalagi dengan hadirnya beragam produk dan jasa keuangan kontemporer mengikuti perkembangan zaman yang dinamis dalam roda perekonomian modern, kewajiban bagi setiap muslim untuk membekali dirinya dengan keilmuan dan pemahaman fikih muamalah. Sarana membangun paradigma ekonomi syariah di masyarakat salah satunya dengan mengoptimalkan peran masjid sebagai pusat dakwah dan pengajian dengan eksistensi majelis taklim ekonomi syariah melalui kajian fikih muamalah.

\section{DAFTAR PUSTAKA}

Anafarhanah, S. (2015). Peran Ekonomi Islam dalam Dakwah Nabi Muhammad SAW. Alhadharah: Jurnal Ilmu Dakwah, 14(28), 1-10. https://doi.org/10.18592/alhadharah.v14i28.1230

Arifin, B. (2015). Eksistensi Maqasid al-Shari'ah Imam aL-Syathiby Dalam Perkembangan Hukum Ekonomi Syari'ah. At-Tahdzib: Jurnal Studi Islam dan Muamalah, 3(2), 75-99.

'Assal, A. M., \& Karim, F. A. A. K. (1977). An-Nizhâm al-Iqtishâdi fì alIslâm. Cairo.

Asyhad, M., \& Handono, W. A. (2019). Urgensi Literasi Keuangan Syariah Pada Pendidikan Dasar. MIYAH: Jurnal Studi Islam, 13(01), 126-143.

Azhari, F. (2014). Qawaid Fiqhiyyah Muamalah. Banjarmasin: Lembaga Pengembangan Kualitas Umat.

Bik, M. al-Khudharî. (2018). Târîkh at-Tasyrî' al-Islâmî. Beirut: Dâr alKutub al-'Ilmiyyah.

Budiman, M. A. (2017). Peran Masjid Dalam Pengembangan Ekonomi Syariah Di Kota Banjarmasin. At-Taradhi: Jurnal Studi Ekonomi, 7(2), 175-182. https://doi.org/10.18592/at-taradhi.v7i2.2014

Fikri, A. (1939). Al-Mu'âmalât al-mâdiyah wa al-adabiyah. Cairo: Mustafa al-Babi al-Halabi. 
Hakim, A. A. (2011). Fiqih perbankan syariah: Transformasi fiqih muamalah ke dalam peraturan perundang-undangan. Bandung: Refika Aditama.

Halabî, A. bin M. bin M. A. al-W. L. ad-Dîn bin asy-Syihnah ats-Tsaqafi al. (1973). Lisân al-Hukkâm fì ma'rifah al-Ahkâm. Kairo: al-Babi alHalabi.

Halim, A. (2008). Politik hukum Islam di Indonesia: Kajian posisi hukum Islam dalam politik hukum pemerintahan Orde Baru dan era reformasi. Badan Litbang dan Diklat, Departemen Agama RI.

Hamid, M. A. (2008). Membumikan ekonomi Syariah di Indonesia (perspektif sosioyuridis). Jakarta: eLSAS.

Hidayatullah, M. S. (2017). Perbankan Syariah: Pengenalan Fundamental dan Pengembangan Kontemporer. Banjarbaru: Dreamedia.

Hidayatullah, M. S. (2020). Islamic Economics And Partial-Total Religiosity: A Case Study Of Majlis Taklim In Banjarmasin. Islamuna: Jurnal Studi Islam, 7(1), 36-55. https://doi.org/10.19105/islamuna.v7i1.3308

Iskandar, A., \& Aqbar, K. (2019). Kedudukan Ilmu Ekonomi Islam di antara Ilmu Ekonomi dan Fikih Muamalah: Analisis Problematika Epistemologis. NUKHBATUL 'ULUM: Jurnal Bidang Kajian Islam, 5(2), 88-105. https://doi.org/10.36701/nukhbah.v5i2.77

Mardani. (2011). Ayat-ayat dan hadis ekonomi syariah. Jakarta: Rajawali Pers.

Munawwir, A. W. (1997). Kamus al-Munawwir Arab-Indonesia Terlengkap. Surabaya: Pustaka Progresif.

Nafi, M. (2017). Hybrid Contract pada Perbankan Syariah dalam Perspektif Maqashid Syari'ah. Yogyakarta: Diandra Kreatif.

Pusat Bahasa Departemen Pendidikan Nasional. (2008). Kamus Bahasa Indonesia. Jakarta: Pusat Bahasa Departemen Pendidikan Nasional.

Qal'ah, M. R. (2000). Mabâhits al-Iqtishâd fî al-Islâmî. Kuwait: ar an-Nafas. Qazwînî, A. A. M. B. Y. bin M. al. (2012). Sunan Ibnu Mâjah (Vol. 3). Beirut: Dâr al-Kutub al-'Ilmiyah.

Ridhwân, S. 'Abdul H. (1996). Aswâq al-Awrâq al-Mâliyyah. Cairo: Ma'had al-'Alamî lil fikr al-Islâmî.

Rijal, A. (2013). Utang Halal Utang Haram. Jakarta: Gramedia Pustaka Utama.

\footnotetext{
URGENSI MEMPELAJARI FIKIH MUAMALAH DALAM MERESPON

58 EKONOMI DAN KEUANGAN KONTEMPORER

Muhammad Syarif Hidayatullah
} 
Sahroni, O. (2019). Fikih Muamalah Kontemporer. Jakarta: Republika.

Sa'id, A. S. F. (1402). Al-Mu'âmalat fì al-Islâm. Mekkah: Rabithah alA'lam.

Syafe'i, R. (2001). Fiqh Muamalah. Bandung: Pustaka Setia.

Syâfi'î, M. bin I. asy. (1985). Dîwân asy-Syâfi'î. Kairo: Maktabah alKulîyat al-Azhariyah.

Syahâtah, H. (t.t.). الالتزام بالضو ابط الثر عية فى المعاملات ضرورة دينية وحاجة اقتصادية. Diambil $10 \quad$ Juli 2020, dari http://www.darelmashora.com/Default.aspx?DepartmentID=2 6

Syarbînî, S. M. bin A. al K. asy. (1994). Mughnî al-Muhtâj ilâ ma'rifah ma'ânî Alfâzhi al-Minhâj (Vol. 2). Beirut: Dâr al-Kutub al'Ilmiyah.

Tirmidzî, A. 'îsâ M. bin 'îsâ bin S. bin M. bin adh D. at. (1998). Sunan atTirmidzî (Vol. 3). Beirut: Dar al-Gharb al-Islami.

Zarqâ, M. A. az. (2004). Al-Madkhal al-Fiqhî al-'âm. Damaskus: Dâr alQâlam.

Zuhailî, W. Az. (1985). Al-Fiqh al-Islâmî wa Adillatuh (Vol. 1). Damaskus: Dâr al-Fikr. 